\title{
SINGLE-SEX PUBLIC SCHOOLS: THE LAST BASTION OF "SEPARATE BUT EQUAL"?
}

In Brown v. Board of Education, Chief Justice Warren stated unequivocally that, "[I]n the field of public education the doctrine of "separate but equal' has no place. Separate educational facilities are inherently unequal." The backdrop for Brown was, of course, discrimination by race, and until recently no court had seriously questioned the constitutionality of public schools segregated on the basis of sex. ${ }^{2}$ However, both the evolving standard of equal protection ${ }^{3}$ as applied to discrimination by sex and the Equal Educational Opportunities Act of $1974^{4}$ raise difficult questions as to the continued validity of single-sex public schools. In this Note, these constitutional questions will be discussed in light of the standards of equal protection enunciated since Reed $v$. Reed. ${ }^{5}$ The focus of this analysis will be on the place, if any, of the doctrine of "separate but equal" in the area of discrimination by sex. Finally, the applicability and significance of the Equal Educational Opportunities Act to single-sex public schools will be examined, with emphasis on its perplexing legislative history.

Historically, single-sex primary and secondary schools have been a rarity in American public education. ${ }^{6}$ From their inception, American public schools were generally open to both sexes. In the smaller settlements, of course, coeducation was mandated by considerations of economy and convenience; but even in the more densely populated eastern cities where single-sex schools posed no such financial or logistical problems, there was little demand for segregation by sex, and coeducation was the norm. One English commentator, in contrasting the American preference for coeducation with Britain's long history of single-sex schools, theorized that the mixed school was "the embodiment of the American doctrine of equal educational opportunities for all."7 The relatively few single-sex public

THE FOLLOWING CITATION WILL BE USED IN THIS NOTE:

Gunther, The Supreme Court, 1971 Term-Foreword: In Search of Evolving Doctrine on a Changing Court: A Model for a Newer Equal Protection, 86 HARV. L. Rev. 1 (1972) [hereinafter cited as Gunther].

1. 347 U.S. 483,495 (1954).

2. See, e.g., Williams v. McNair, 316 F. Supp. 134 (D.S.C. 1970), aff'd, 401 U.S. 951 (1971); Allred v. Heaton, 336 S.W.2d 251 (Tex. Civ. App.), cert. denied, 364 U.S. 517 (1960); Heaton v. Bristol, 317 S.W.2d 86 (Tex. Civ. App.), cert. denied, 359 U.S. 230 (I958).

3. See generally Gunther; Johnston, Sex Discrimination and the Supreme Court-19711974, 49 N.Y.U.L. Rev. 617 (1974); Developments in the Law-Equal Protection, 82 HaRv. L. REv. 1065 (1969).

4. 20 U.S.C. $\S \S 1701-1758$ (Supp. IV 1974).

5. 404 U.S. 71 (1971).

6. B. Howard, The Mixed SCHOOL: A STUdy OF COEduCation 41-48 (1928).

7. Id. at 41 . Besides the ideological overtones of coeducation, mixed schools were viewed 
schools which have survived to the present generally possess unique attributes, either in the nature of their curriculum or the characteristics of the student body, which traditionally have been viewed as justification for the segregation of the school by sex. ${ }^{8}$ However, given the diminishing strength of most sex-role expectations, ${ }^{9}$ the continued maintenance of single-sex public schools can be viewed as a means of reinforcing patterns of discrimination by sex and raises questions of constitutional magnitude.

\section{The Standard of Review in Sex Discrimination Cases}

Until 1971, the judicial treatment of legal classification by $\operatorname{sex}^{10}$ amounted to little more than total deference to legislative sentiment regarding the proper role of women in society. ${ }^{11}$ In seeking out a "rational relation" between a legislative classification and a legitimate state interest, the courts hypothesized justifications which often did not even purport to reflect the actual objective of the classification. ${ }^{12}$ The judiciary had essentially abdicated any role in the review of Jegislative classifications by gender. ${ }^{13}$

as providing a healthier atmosphere for learning. The American system was praised for achieving "a complete absence of sex-strain" and an "intellectual stimulus due to the intellectual differences between boys and girls." Id. at 43.

8. See Note, Academic High Schools: The Need for Equal Protection for Girls, 8 U.S.F.L. REv. 639, 641-43 (1974).

9. One need only read the newspapers to perceive the general blurring of traditional sex-role distinctions. In Stanton v. Stanton, 421 U.S. 7 (1975), the Supreme Court stated that this change in the perception of women's roles is a proper subject for judicial consideration. In striking down a state law making the age of majority higher for men than for women, Justice Blackmun wrote:

No longer is the female destined solely for the home and the rearing of the family and only the male for the marketplace and the world of ideas . . . . Women's activities and responsibilities are increasing and expanding.... The presence of women in business, in the professions, in government and, indeed, in all walks of life where education is a desirable, if not always a necessary, antecedent, is apparent and a proper subject of judicial notice.

Id. at 14-15.

10. The literature in this area is extensive. The reader is directed to Professor Gunther's article, as well as to Ginsburg, Gender in the Supreme Court: The 1973 and 1974 Terms, 1975 SUP. CT. REv. 1, and Johnston, supra note 3.

11. Three cases provided the analytical framework for sustaining legislative classifications by sex: Muller v. Oregon, 208 U.S. 412 (1908) (sustaining regulation of work hours of women, based on "Brandeis brief" documentation of the special needs of women); Goesaert v. Cleary, 335 U.S. 464 (1948) (upholding statute prohibiting employment of female bartenders not related to the bar owner); and Hoyt v. Florida, 368 U.S. 57 (1961) (upholding law by which women's names were placed on jury lists only upon special request). It should be noted that Hoyt was effectively overruled in Taylor v. Louisiana, 419 U.S. 522, 537 (1975).

12. In Goesaert v. Cleary, 335 U.S. 464 (1948), Justice Frankfurter wrote, "If [a justification for the classification] is entertainable . . . Michigan has not violated its duty to afford equal protection of its laws. We cannot cross-examine either actually or argumentatively the mind of Michigan legislators nor question their motives." Id. at 466-67. See also Developments in the Law, supra note 3, at 1080.

13. The closest analogy to the judicial deference accorded legislative classifications by sex is in the area of equal protection challenges to economic regulations. See, e.g., Williamson v. 
The Supreme Court's unanimous decision in Reed v. Reed, ${ }^{14}$ however, marked the transition to a more stringent standard of review in the area of sex discrimination. In striking down an Idaho probate code provision under which men were given mandatory preference over women in the appointment of administrators and executors, the Court deemed the legislature's purported concerns for administrative efficiency and the lessening of intrafamilial dispute to provide insufficient justification for the classification. Although the Reed Court neither acknowledged a break with precedent nor precisely enunciated a more stringent standard of review, it is impossible to square this result with a rational relation analysis; some have suggested that the Court's holding is comprehensible only if a suspect classification method of analysis is assuned. ${ }^{15}$ This conclusion is supported by the Court's perfunctory labeling of the legislative classification as impermissibly "arbitrary," even though the state offered a justification which was apparently sufficient to make the choice constitutionally defensible under even an intermediate standard of review. ${ }^{16}$ In short, the Reed Court's close examination of the facts in discerning the relationship between the classification and a permissible state objective heralded an end to the judicial attitude of total deference in the area of sex discrimination.

Reed's implication that sex is to be treated as a suspect classification appeared to become an express standard in Frontiero v. Richardson. ${ }^{17}$ In striking down a statute which required female, but not male, Army personnel to prove that their spouse was a dependent in order to qualify for special

Lee Optical Co., 348 U.S. 483 (1955); Daniel v. Family Security Life Ins. Co., 336 U.S. 220 (1949); Railway Express Agency v. New York, 336 U.S. 106 (1949).

14. 404 U.S. 71 (1971).

15. It is difficult to understand [the] result without an assumption that some special sensitivity to sex as a classifying factor entered into the analysis. Clear priority classifications are plainly relevant to the State's interest in reducing administrative disputes. Even if the requirement be that the means bear a "significant relationship" to the state's purpose... . the test would seem to have been met in Reed. Only by importing some special suspicion of sex-related means from the new equal protection area can the result be made entirely persuasive.

Gunther 34. See also Note, The Emerging Bifurcated Standard for Classifications Based on Sex, 1975 DukE L.J. 163, 177-79.

16. Gunther 34. The intermediate standard demands simply that the "legislative means must substantially further legislative ends." Id. at 20. The actual formulation in Reed is taken from F.S. Royster Guano Co. v. Virginia, 253 U.S. 412 (1920), which states that a classification must rest on a "ground of difference having a fair and substantial relation to the object of the legislation." Id. at 415; see Reed v. Reed, 404 U.S. 71, 76(1971). The Reed Court acknowledged that the statutory preference for male executors serves the legitimate state interest of reducing the workload of probate courts by eliminating a time-consuming issue, i.e., whom to appoint as executor when both a male and a female file a petition for that position. Id. Moreover, given the state's premise that most men are more knowledgeable about business affairs than most women, the classification bears a fairly tight fit to the state objective of appointing the most qualified person without the need of examining the education and experience of each petitioner. In short, the classification does substantially serve the legitimate state goal of expediting one phase of probate without undue detriment to the estate.

17. 411 U.S. 677 (1973). 
allowances, the Court found the Army's interest in administrative efficiency insufficiently strong to sustain a classification by sex. ${ }^{18}$ In a radical departure from precedent, four Justices joined in declaring that sex would be treated the same as race and national origin for equal protection purposes. ${ }^{19}$ This bold proclamation of the plurality, however, has never been adopted by a majority of the Court, and subsequent cases have clearly retreated from the proposition that sex is a suspect classification.

Two recent cases involving arguably "benign" classifications, Kahn v. Shevin ${ }^{20}$ and Schlesinger $v$. Ballard, ${ }^{21}$ revealed a temporary return to the familiar minimal scrutiny analysis. In Kahn, the Court upheld a Florida statute giving widows, but not widowers, a $\$ 500$ property tax exemption. Positing that "[t]here can be no dispute that the financial difficulties confronting the lone woman in Florida or in any other State exceed those facing a man,"22 the Court concluded that the statute was "reasonably designed to further the state policy of cushioning the financial impact of spousal loss upon the sex for whom that loss imposes a disproportionately heavy burden." 23 In Ballard, Navy tenure standards giving women more time than men to achieve required promotions were upheld on the ground that "Congress may . . . rationally have believed that women line officers had less opportunity for promotion than did their male counterparts. . . ."24 One commentator has suggested that this use of minimal scrutiny language in Kahn and Ballard indicates that "ameliorative" sex-based classifications will be subject to the least stringent of equal protection standards, while classifications disadvantageous to women will be subject to strict scrutiny. ${ }^{25}$ This best-of-all-worlds proposition has been properly criticized ${ }^{26}$ in light of Geduldig v. Aiello, ${ }^{27}$ in which the Court upheld the constitutionality of

18. Id. at 690-91.

19. Id. at 688. Mr. Justice Powell decried this plurality position as both an unnecessary extension of Reed and an unwarranted assumption of "decisional responsibility" at a time when the same question was before the state legislatures in the form of the Equal Rights Amendment. Id. at 692 (Powell, J., concurring in the result).

20. 416 U.S. 351 (1974).

21. 419 U.S. 498 (1975).

22. 416 U.S. at 353.

23. Id. at 355. Justice Douglas sidestepped the fact that the classification was terribly overbroad, in that the tax exemption was given to women regardless of need. The state could have made the exemption conditional on the taxpayer's income, but chose not to for reasons of administrative convenience. Justice Douglas attempted to distinguish Frontiero, which stated that administrative convenience was not enough by itself to justify a classification by sex, by noting that the state should be given greater leeway in the exercise of its taxing power. $I d$. This is a dubious distinction.

24. 419 U.S. at 508.

25. Note, supra note 15 , at 164 .

26. Ginsburg, supra note 10 , at 8 . This is not to say, however, that the outcomes of Kahn and Ballard were not significantly affected by the Court's perceptions that these gender-based classifications were socially desirable. See Craig v. Boren, 97 S. Ct. 451,457 n.6 (1976).

27. 417 U.S. 484 (1974). See also General Elec. Co. v. Gilbert, 97 S. Ct. 401 (1976) 
California's disability income program which excluded disability related to normal pregnancy. Although the benign quality of a classification may indicate that the state harbors no invidious motives, this distinction does not appear to be a sufficient basis for an enduring equal protection standard in the area of sex discrimination. ${ }^{28}$

The most recent case in the area of sex-based classifications, Craig $v$. Boren, ${ }^{29}$ is important in several respects. First, it confirms the existence of an intermediate standard of review; second, it apparently makes this standard applicable even when the classification has a benign effect on females; and third, it sets out a new formulation of the intermediate standard. Since the members of the Court wrote seven opinions in the 7-2 decision, it is clear that Craig will not be the last word in this area; however, its implications must be closely examined.

(upholding, in face of Title VII challenge, exclusion of normal pregnancy from comprehensive sickness and accident benefit plan given all employees).

Although both Geduldig and Gilbert arguably involve a gender-neutral exclusion of one type of health disability, 417 U.S. at $496 \mathrm{n} .20$, such reasoning is problematic. See General Elec. Co. v. Gilbert, 97 S. Ct. 404, 416 (1976) (Brennan, J., dissenting). Employers are obviously reasonable in seeking to avoid the high costs of including recurring conditions like pregnancy in their benefit plans; but, to be genuinely gender-neutral, the exclusion would have to encompass all disorders and abnormal conditions of the human reproductive system. The GE plan, however, insured against such risks as prostatectomies, vasectomies and circumcisions. Id. The inclusion of the latter two maladies also makes questionable the majority's attempt to distinguish pregnancy from other health-related disabilities by insisting that it is a wholly "voluntary" condition. Id. at $415-16$.

28. In a recent case involving "benign discrimination," the Court invalidated a Social Security Act provision requiring widowers, but not widows, to prove actual dependency on the deceased spouse in order to qualify for survivor's benefits. Califano v. Goldfarb, $97 \mathrm{~S}$. Ct. 1021 (1977). The Secretary argued that the statistically small incidence of men being dependent on their wives for financial support gave Congress reasonable grounds for the gender-based distinction. Citing Craig v. Boren, 97 S. Ct. 451 (1976), for the proposition that a gender-based discrimination against men will fail unless it serves an important governmental objective and is substantially related to the achievement of that objective, Justice Brennan struck down the provision as being based on nothing more than archaic and overbroad generalizations. $97 \mathrm{~S}$. Ct. at 1032. Justice Stevens concurred on the ground that, when Congress used the term "widow," it really meant "surviving spouse." Id. at 1035.

In a significant dissenting opinion, Justice Rehnquist acknowledged that administrative convenience will not generally sustain a classification by gender (citing Frontiero v. Richardson, 411 U.S. 677 (1973)), but insisted that such a basis is adequate in "social welfare" cases. 97 S. Ct. at 1041. In devising an equal protection standard that turns on whether the interest at stake is a creature of social welfare legislation, Justice Rehnquist appears to reflect the Court's renewed tendency in procedural due process cases to balance the public interest against private interests. See generally Mathews v. Eldridge, 424 U.S. 319 (1976). Regardless of the merits of this development in the due process area, it appears to be singularly inappropriate to equal protection analysis.

Despite Goldfarb, it appears that the concept of benign discrimination still has some utility. See Califano v. Webster, 97 S. Ct. 1192 (1977) (per curiam reversal of district court decision which had struck down gender-based difference in the calculation of Social Security benefits).

29. 97 S. Ct. 451 (1976). 
In striking down Oklahoma's sex-based age differential for the legal consumption of beer, Justice Brennan stated that a legislative classification by sex must be founded on more than a "weak congruence" between sex and the characteristic or trait that sex purports to represent. ${ }^{30}$ The trait that sex purported to represent here-a propensity to drive while drunk-was viewed as bearing too tenuous a "fit" to the classification by sex,${ }^{31}$ despite evidence showing that more than eighteen times as many 18-to-20-year-old males as females were arrested for driving under the influence of alcohol. ${ }^{32}$ Justice Brennan insisted that "[W]hile such a disparity is not trivial in a statistical sense, it can hardly form the basis for employment of a gender line as a classifying device." 33

After reviewing the decisions since Reed, the majority devised a formulation of the intermediate standard of review: "To withstand constitutional challenge, previous cases establish that classifications by gender must serve important governmental objectives and must be substantially related to achievement of those objectives." 34 The Oklahoma statute fell on the "substantially related" requirement. Justice Brennan, after dismissing the state's data showing higher rates of arrests and accidents for 18-to-20-yearold males than females, noted that the surveys failed to measure both the dangerousness of 3.2 beer (as opposed to alcohol generally) and the propensity for drunken driving as functions of age. ${ }^{35}$ Given these deficiencies in the "fit" between the classification and the trait, the statute "invidiously discriminated" against males eighteen to twenty years of age. ${ }^{36}$

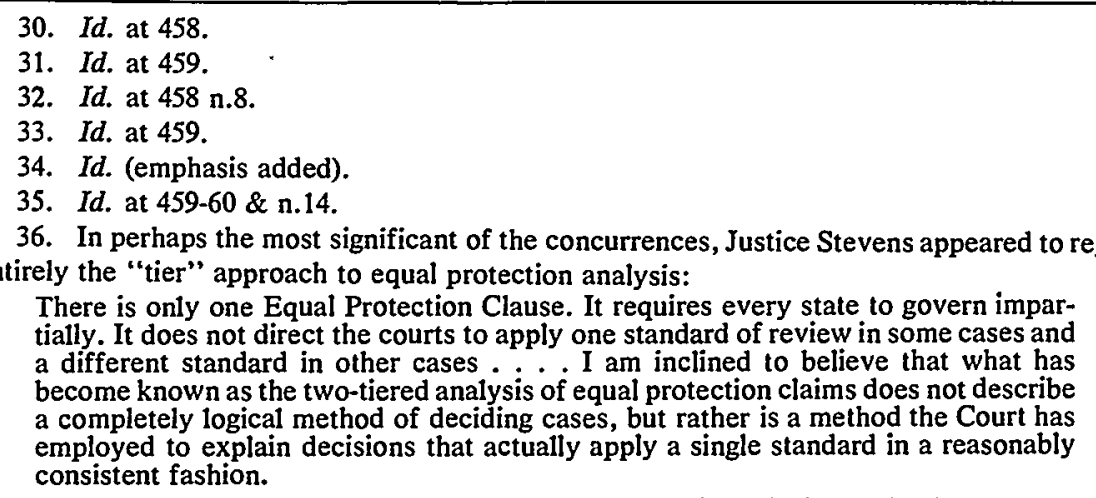

Id. at 464 . Although he provided only the broad outline of his analysis, Justice Stevens seems to suggest a two-step approach. He first asked if the classification was "objectionable," id. at 465 , a term which he did not define. It appears, however, to be synonomous with "obnoxious" and "offensive." See id. at 464-65. If the classification is objectionable, the court must then inquire whether the state can put forward a justification "sufficient to make an otherwise offensive classification acceptable." Id. at 465 . Justice Stevens found the Oklahoma statute in Craig objectionable because it turned on an accident of birth, because it reflected socially outmoded biases, and because it actually restricted the wrong sex in terms of physical ability to tolerate alcohol from drinking beer. Id. Although he conceded that the classification was not "totally irrational," Justice Stevens found no logical justification sufficient to make the offensive classification acceptable. Id. 
In light of Craig, it now can be confidently stated that the proper standard of review in sex discrimination cases is something intermediate between a rational relation analysis and a strict scrutiny test. However, uncertainty remains as to how courts will apply Justice Brennan's formulation calling for an "important" governmental interest and a "substantial" relation of the classification to the state's objectives. Since most lower courts already apply some type of heightened scrutiny to gender-based classifications, ${ }^{37}$ it is unlikely that the results in a significant number of

Justice Stevens' apparent rejection of the tier model of equal protection, coupled with his adoption of a flexible standard of equal protection, has important implications. See Yarbrough, The Burger Court and Unspecified Rights: On Protecting Fundamental And Not-SoFundamental "Rights" or "Interests" Through a Flexible Conception of Equal Protection, 1977 DUKE L.J. 143, $162 \mathrm{n} .111$ and accompanying text. Under a unified approach, suspect classification analysis could be limited to race, which is the only classification to which the equal protection clause was originally addressed. Id. Other suspect and semi-suspect classifications would be subjected to a balancing-of-interests analysis of the type described by Justice Stevens. Although a flexible standard would be conceptually less precise than the present tier approach, it has the advantage of forcing courts to articulate those bases for their decisions which currently lie submerged beneath the conclusory labels of suspect classification, rational relation and compelling interest. Labeling a classification as suspect is little more than an obtuse shorthand for Justice Stevens' inquiry into whether a state can offer sufficient justification to make an otherwise offensive classification acceptable. The advantages of this above-the-table interestbalancing approach are even more apparent with regard to the fundamental rights branch of equal protection analysis. See id.

The Craig dissenters rejected the majority's use of an intermediate standard of review. Chief Justice Burger rejected such a standard as applied in any sex discrimination case, $97 \mathrm{~S}$. Ct. at 466-67, while Justice Rehnquist expressed alarm at its application to invalidate a statutory discrimination harmful to males. Id. at 468-69. Citing San Antonio Indep. School Dist. v. Rodriguez, 411 U.S. 1 (1973), the Chief Justice demanded that there be a "textually independent constitutional status" in order to afford gender any preference for equal protection purposes. Id. at 467 . This analysis, however, would appear to confuse fundamental rights with suspect classifications.

37. The lower courts were not without their problems in discerning and applying the equal protection standards enunciated in Reed and such subsequent cases as Stanton v. Stanton, 421 U.S. 7 (1975) (striking down as "irrational" Utah law making age of majority higher for males than females), and Weinberger v. Wiesenfeld, 420 U.S. 636 (1975) (striking down social security provision granting benefits to wife, but not husband, of a deceased wage earner with minor children). As a caveat to his analysis of the area, one district court judge noted that, "A lower court faced with this line of cases has an uncomfortable feeling, somewhat similar to a man playing a shell game who is not absolutely sure there is a pea." Vorchheimer v. School Dist. of Philadelphia, 400 F. Supp. 326, 340-41 (E.D. Pa. 1975) (discussed at notes $41-44$ infra and accompanying text). If any generalization can be made about the behavior of the lower courts in the area of sex discrimination, it is that their actions accorded almost exactly with those of the Supreme Court prior to Craig, i.e., they employed the language of minimal scrutiny while generally applying (either expressly or sub rosa) some variation of the intensified, meansfocused standard of review described by Professor Gunther, see Gunther 36. See, e.g., Crawford v. Cushman, 531 F.2d 1114, 1123 (2d Cir. 1976) (striking down as "irrational" a Marine Corps regulation mandating the discharge of pregnant Marines); White v. Fleming, 522 F.2d 730, 733-36 (7th Cir. 1975) (striking down ordinance prohibiting female tavern employees from sitting with male patrons); Fortin v. Darlington Little League, Inc., 514 F.2d 344, 348 (1st Cir. 1975) (striking down league regulation prohibiting girls from playing on team); Berkelman v. San Francisco Unified School Dist., 501 F.2d 1264, 1269 (9th Cir. 1974) (striking down admissions policy allowing admission of boys less qualinitied than some girls denied admission); 
future cases will turn solely on the difference, if any, between the Brennan formulation and the formulations previously employed in most circuits. Nonetheless, Craig is significant insofar as it clears the air of doubts regarding the continued application of the minimal scrutiny standard to certain types of sex-based classifications. Clearly, the Craig formulation allows little room for judicial deference to legislative classifications by sex; future classifications face a standard of review applied with a "new bite."38

\section{The Standard Applied: The Vorchheimer Dilemma}

In Vorchheimer v. School District of Philadelphia, ${ }^{39}$ the question of the constitutionality of single-sex public schools was presented in a context ideally suited for a resolution of lingering questions about segregation by gender. ${ }^{40}$ Susan Vorchheimer, a bright teen-age girl, ${ }^{41}$ was denied admission to Central High School (one of Philadelphia's two "academic schools" which admit only intellectually superior students) on the basis of sex. Vorchheimer subsequently filed a class action in federal district court under both 42 U.S.C. $\S 1983$ and the Pennsylvania Equal Rights Amendment ${ }^{42}$ on

Eslinger v. Thomas, 476 F.2d 225, 230-31 (4th Cir. 1973) (striking down state senate resolution permitting females to serve as clerical assistants but not as pages). However, a few circuits have clung to the "original understanding" of the rational relation test, and require only the weakest of justifications to sustain a classification by sex. See, e.g., Smith v. Troyan, 520 F.2d 492,496 (6th Cir. 1975) (sustaining a height requirement for police personnel as rational on the ground that most municipalities still utilize such a requirement); Robinson v. Board of Regents, 475 F.2d 707 (6th Cir. 1973) (upholding university curfew rules applicable to women only). Contra, Morris v. Michigan State Bd. of Educ., 472 F.2d 1207 (6th Cir. 1973) (invalidating high school regulation prohibiting girls from participating with boys in interscholastic athletic contests). These decisions appear to be inconsistent with the tenor of most thinking on the subject and with the Supreme Court's view. See, e.g., Johnston, supra note 3, at 688-92.

38. Gunther 36.

39. 400 F. Supp. 326 (E.D. Pa. 1975), rev'd, 532 F.2d 880 (3d Cir.), cert. granted, 97 S. Ct. 252 (1976). As this Note went to press, the Supreme Court handed down a decision in Vorchheimer. 45 U.S.L.W. 4350 (U.S. April 20, 1977). By an evenly divided vote (Justice Rehnquist not participating), the Court affirmed the decision of the Third Circuit. No opinions accompanied the announcement of the decision.

40. Williams v. McNair, 316 F. Supp. 134 (D.S.C. 1970), aff'd mem., 401 U.S. 95 I (1971), presented a superficially similar, but easily distinguishable, problem. There a male was denied admission to Winthrop College, an all-female state school. In upholding the school's admissions policy, the district court noted that all other South Carolina state colleges, with the exception of the Citadel, were coeducational, and offered as good an education as Winthrop. Williams seems of little precedential value, since Philadelphia offered Vorchheimer but one school, Girls High, which was suitable to her abilities, and that school was clearly inferior to the all-boys school in its science facilities and arguably inferior in other ways. See $400 \mathrm{~F}$. Supp. at 328. See notes 52-63 infra and accompanying text.

41. The plaintiff's academic junior high school awarded her the school prizes in geometry, science, history and English; she also received the American Legion award for citizenship and the most outstanding student award. $400 \mathrm{~F}$. Supp. at 328.

42. PA. ConST. art. $1, \S 28$. The district court declined to exercise pendent jurisdiction over this state law claim, since the amendment had yet to be the subject of litigation at the state court level. 
behalf of all qualified females who had been or would be denied admission to Central on the basis of sex. In response to Vorchheimer's claim of unlawful discrimination, the Philadelphia school district proffered two purportedly empirical studies supporting segregation by sex in schools. ${ }^{43}$ Neither study, however, dealt precisely with the issue before the court.

Applying an intermediate standard of review, ${ }^{44}$ the district court expressed great difficulty in accepting these tenuously relevant studies as evidence that segregation by sex bore a fair and substantial relation to the city's generalized interest in educating its children and producing good citizens. The court found it hard to believe that anything more than tradition was sustaining the sex segregation of Girls High School and Central in view of the fact that nearly the entire school system was coeducational. Based on these considerations, an order was issued enjoining the school board from refusing to admit Vorchheimer and members of her class to Central on the basis of sex.

Writing for the Third Circuit, Judge Weis reversed. ${ }^{45}$ In a perplexing opinion, the court avoided saying whether it ought to apply minimal scrutiny or some intermediate standard of review by declaring that it made no difference on the facts before it. ${ }^{46}$ The need to allow "innovation in methods and techniques" was found to be adequate justification for segregation by sex, despite the fact that the weight of educational theory (the defendant's "empirical" evidence notwithstanding) ${ }^{47}$ gave little support for such techniques. ${ }^{48}$

43. The Tidball Study showed that, from 1910 to 1950, Who's Who of American Women contained two to three times as many graduates of women's colleges as from coed schools. The problems with the Tidball methodology seem obvious. First, the comparison of absolute numbers is meaningless; a significant comparison would be weighted according to the numbers of women who had attended the two types of colleges. Further, because there could be no effective control for the woman's social standing and economic status (both of which are related to the probability of having one's name in Who's Who), any conclusion that single-sex education contributed to personal achievement as reflected by inclusion in Who's Who is little more than speculation. It has also been noted that:

A 1910's to 1950's Who's Who search would turn up not a single woman achiever

from the nation's most prestigious, richly endowed colleges. For the gates of, e.g.,

Princeton, Yale, Harvard, Dartmouth, Brown, Amherst, like Central's door today, were then shut to women.

Petition for Writ of Certiorari at 19 n.11, Vorchheimer v. School Dist. of Philadelphia, 97 S. Ct. 252 (1974). The second study examined selected attitudes (but not achievements) of average students in New Zealand's comprehensive schools. The researcher conceded that the study was largely uninstructive as to the relative merits of single-sex schools for academically gifted American students. $400 \mathrm{~F}$. Supp. at 330-32.

44. See note 37 supra and accompanying text.

45. 532 F.2d 880 (3d Cir. 1976).

46. Id. at 888 .

47. See note 43 supra.

48. The most comprehensive empirical study of the merits of coeducation is R. DALE, MiXed OR SINGLE-SEX SCHOOL? (1969). This three-volume work examines three areas: pupilteacher relationships, attainment of societal objectives, and student achievement. Although the 
Even if its deference to the school district was warranted and its understanding of the Reed series of cases was correct, the Third Circuit's opinion is disturbing because of dicta which suggest that an alternative basis for the finding of no denial of equal protection was that "separate but equal" facilities were available. In a significant section of the opinion, the court distinguished Reed, Frontiero and Stanton by noting that

[i]n each instance where a statute was struck down, the rights of the respective sexes conflicted, and those of the female were found to be inadequate. None of the cases was concerned with a situation in which equal opportunity was extended to each sex or in which the restriction applied to both .... The plaintiff [here] has difficulty in establishing discrimination in the school board's policy. ${ }^{49}$

It is difficult to avoid concluding that the Vorchheimer court believed the city's policy of sex segregation in its "academic" schools to be based on a theory of equal benefit and, therefore, simply not to be a denial of equal protection..$^{50}$ The acceptance of such a theory, however, ignores several relevant considerations in the area of discrimination by sex.

\section{A Lingering Doubt: CAN All-Girl Schools Be Separate BUT EQUAL TO ALL-BOY SCHOOLS?}

The problem with the Vorchheimer majority's theory of equal benefit is analogous to the problem with Plessy v. Ferguson's $\mathrm{s}^{51}$ concept of "separate but equal." Each involves a failure to perceive that when two groups of presently unequal status are segregated solely on the basis of that status, separate rarely can be equal. Even before Brown, the Court had recognized that, in the area of education, the mere equivalency of designated tangibles (e.g., number of faculty, size of library, quality of buildings) does not necessarily provide an equality of educational opportunity. ${ }^{52}$ Such intangibles as tradition, standing in the community, position and influence of the

studies do not uniformly reveal advantages in coeducation, the author's conclusion is that the advantages strongly outweigh the disadvantages. See 3 id. at 229-74.

49. 532 F.2d at 886 (emphasis added).

50. Id. at 887 . The majority actually ascribed to the plaintiff herself a concession that the schools were in fact equal. The court stated:

A fair summary of the parties' positions, therefore, is that:

4. the deprivation asserted is that of the opportunity to attend a specific school, not that of an opportunity to obtain an education at a school with comparable academic facilities, faculty and prestige.

Id. at 882. Judge Weis' misunderstanding of the facts is reflected in his formulation of the question before the court: "Do the Constitution and laws of the United States require that every public school, in every public school system in the Nation, be coeducational?" Id. at 881.

51. 163 U.S. 537 (1896). In his dissent, Judge Gibbons summarized the majority opinion by paraphrasing Plessy. 532 F.2d at 889.

52. Sweatt v. Painter, 339 U.S. 629, 632-36 (1950); McLaurin v. Oklahoma State Regents, 339 U.S. 637, 641-42 (1950); see Missouri ex rel. Gaines v. Canada, 305 U.S. 337, 350-52 (1938). 
alumni, and prestige are certainly as important in the determination of equality in the area of education. A further consideration in examining sex-segregated schools is the relative deprivation entailed in not being able to make friends and acquire "contacts" among the group (the males at Central) who probably will continue to dominate the business and professional life of the community. A final factor, perhaps one of less constitutional significance than the others, is the possibility that the same psychological damage ("feeling of inferiority") discussed in Brown ${ }^{53}$ might occur among girls denied access to the facilities provided to boys. ${ }^{54}$ Each of these factors must be considered in determining whether educational facilities segregated on the basis of sex are inherently unequal.

\section{A. The Intangibles: Position and Prestige}

In Sweatt v. Painter ${ }^{55}$ the Court recognized that equality of educational opportunity requires more than an equivalence of faculty and facilities. Striking down a state's attempt to maintain a separate, all-black law school, the Court insisted that relevant factors include "those qualities which are incapable of objective measurement but which make for greatness in a law school. Such qualities . . . include reputation of the faculty, experience of the administration, position and influence of the alumni, standing in the community, traditions and prestige." 56

Although these considerations are less striking in the case of high schools, they are relevant, especially in the context of distinguished academic schools which have unique traditions and a definite standing in the

53. Brown v. Board of Educ., 347 U.S. 483, 494 (1954).

54. The relevance of sociological and psychological data to constitutional decision-making has been a more controversial question than it should be, largely because of a misunderstanding of the uses of such data. For an overview of the controversy, see Gregor, The Law, Social Science, and Social Segregation: An Assessment, 14 W. RES. L. Rev. 621 (1963); Lewis, Parry and Risposte to Gregor's The Law, Social Science, and School Segregation: An Assessment, id. at 637; Gregor, The Law and Social Science: A Reply to Lewis, 15 W. RES. L. REv. 111 (1963). While few would care to build a constitutional doctrine on the shifting sands of social science, certain findings of fact in cases of discrimination necessarily require the application of principles which are far less certain than the laws of physics. For example, it is impossible to prove in a mathematical sense that any environmental factor (e.g., racial discrimination) ever causes a behavioral disorder (e.g., feelings of inferiority). However, there is a general consensus that the foregoing inference of causation is more than mere speculation, and probably rises to the same level of certainty as other legal determinations, e.g., sanity in the context of criminal cases or proximate cause in the tort area. Granted, social science theories do change, and such changes may jeopardize constitutional decisions which include findings based on an earlier theory. However, social change in general, including change in economic conditions, population and life styles, are of constitutional significance and have required revisions of doctrine. In short, social science data, provided it meets current standards of research methodology and commands some consensus, should govern relevant fact determinations until shown to be erroneous.

55. 339 U.S. 629 (1950).

56. Id. at 634 . 
eyes of the community. Because of past domination by males of most social institutions, Central doubtless outstrips Girls among all the relevant intangibles suggested by Sweatt. ${ }^{57}$ Central is the only Philadelphia public school with a substantial private endowment, and its Barnwell Foundation (established by an alumnus) sponsors the visits of distinguished guests. Because of the achievements of its members, the Central Alumni Association is influential in Philadelphia affairs. These are among the intangibles that have characterized Central, and Girls simply cannot claim the same distinction. By denying girls access to a school with such an unequaled history and reputation, the city inflicts on them a significant personal and professional deprivation.

\section{B. Professional Contacts}

It is beyond question that one of the primary advantages of attending a distinguished school is the opportunity to make acquaintances which may be of social and economic value in later life. For a variety of reasons, Central arguably offers its students greater opportunities of this nature than does Girls. At the alumni level, past discrimination fairly guarantees that professional contacts with the Central alumni are more valuable than contacts with the Girls alumnae. ${ }^{58}$ At the student level, which perhaps is more significant, the vestiges of sex discrimination will continue to make one's peer group contacts at Central more valuable in many respects than those available at Girls. While it is difficult to generalize about something as nebulous as interpersonal relations, Judge Weis' conclusion that Girls is separate but equal to Central is clearly open to question on this factor alone.

\section{The Psychological Impact of Segregation by Sex}

In Brown, Chief Justice Warren wrote that the segregation of black children "generates a feeling of inferiority as to their status in the community that may affect their hearts and minds in a way unlikely ever to be undone." 59 Given the similarities between race and sex discrimination, ${ }^{60}$ it

57. 400 F. Supp. at 328-29.

58. Although the Girls alumnae count among their ranks three Philadelphia judges and a past vice president of the American Medical Association, the number of Girls alumnae who have become influential in business, professional or academic affairs does not approach the number in that group who have graduated from Central. Id. at 329.

59. 347 U.S. at 494.

60. The incidents of sex discrimination reveal many parallels to racial discrimination. As a practical matter, both forms of discrimination have resulted in social and professional segregation, confinement to less prestigious jobs, lower incomes, poorer educations and political impotence. Under both types of discrimination, the subservient group has been characterized as being less intelligent, less self-disciplined, less trustworthy and more "instinctual" than the dominant group. Finally, both types of discrimination are facilitated by the high visibility of those physical characteristics which identify the group. See Note, "A Little Dearer Than His Horse:" Legal Stereo-types and the Feminine Personality, 6 HaRv. C.R.-C.L. L. Rev. 260, 
is not beyond reason that women continually discriminated against on the basis of sex will experience some of the same feelings of inferiority. Although few would contend that the manifestations of sex discrimination are as crushingly burdensome or as inescapable as the incidents of racial discrimination, psychological research suggests striking similarities between women and blacks in the consequences of institutionalized discrimination. ${ }^{61}$

In the Vorchheimer situation, the psychological considerations involved in sex segregation arise in subtle, but nonetheless important, ways. Specific incidents of sex discrimination cannot be understood outside the entire pattern of traditional restraints imposed on women, and Susan Vorchheimer's different reactions to Central and Girls must be viewed in that light. Central was founded in 1836 with the immediate intent that it should be a college-preparatory school for intellectually superior boys. On the other hand, the original mission of Girls (founded some time later) was to train public school teachers. Despite the current similarity of the schools in their avowed purpose to prepare the city's best students for college and profes-

274-75 n.109 (1971); Note, Sex Discrimination and Equal Protection: Do We Need an Equal Rights Amendment?, 84 HARV. L. REV. 1499, 1507 (1971).

61. Studies have shown that normal women are more prone than men to feelings of low self-esteem. Gutmann, Female Ego Styles and Generational Conflict, in FEMININe Personality AND CONFLICT 77 (1970). Studies of American children reveal that boys' self-esteem is more. related to internalized standards of achievement while girls depend more on external (and therefore less controllable) sources of approval and acceptance. Douvan, New Sources of Conflict in Females at Adolescence and Early Adulthood, in FEMININE PERSONALITY AND Conflicr 39 (1970). Another researcher has compared the diagnostic classifications of male and female psychiatric patients, and has shown that there are characteristically "male" and "female" types of emotional disturbances. P. CHESLER, WOMEN AND MADNESS 38-49 (1972). Alcoholism, drug addiction and personality disorders are "male diseases," while women are far more prone to depression, paranoia and schizophrenia. Id. at $42-43$. Chesler attributes these gender-based differences to nurture, not nature.

Even intellectually superior girls, who could be expected to be less prone to feelings of inferiority vis-a-vis their male peers, show far less positive attitudes about themselves than do boys. Smith, Sentence Completion Differences Between Intellectually Superior Boys and Girls, 27 J. Projective Tech. AND Personality Assessment 472 (1963). Other research has shown that the values learned by young girls actually instill in them a "motive to avoid success." See generally M. HoRner, SeX Differences in ACHIEvement Motivation AND PERfoRmance IN Competitive and Non-Competrtive Situations (1968). Horner writes, "[T] he arousal of motivation to avoid success may very well account for the major part of the withdrawal of so many trained American women from the mainstream of thought and achievement." Id. at 70. See also Horner, Fail: Bright Women, PsYcholOGY TODAY, November, 1969, at 36. Horner's research methodology, but not her theory, has recently been criticized. See Levine \& Crumrine, Women and the Fear of Success: A Problem in Replication, 80 AM. J. Sociology 964 (1975).

By themselves, these studies do not prove that, in all situations, an all-girl school cannot be equal to an all-boy school. They do, however, give support to the intuitively sound proposition that single-sex schools have been one of the vehicles for inculcating and reinforcing those values which have generally led men to positions of power and women to positions of subservience. 
sional achievement, Girls simply has not kept pace with Central in terms of the achievements of its graduates. ${ }^{62}$

This disparity must ultimately be attributed to general societal discrimination against women; it is apparent, however, that all-girl schools like Girls High have played a role in cultivating the attitudes and behavior of women that have kept the great majority from achieving professional prominence and positions of power, regardless of ability. In other words, the touted educational equivalency of Girls and Central is meaningless unless the students of both schools are inculcated with the same career objectives and attitudes toward professional achievement. In a society in which many still insist there is a vast chasm between the proper roles of men and women, the only way that it can be assured that intellectually superior girls like Susan Vorchheimer will be exposed to the career perspectives and personal values instilled in the boys at Central is to allow them admission to that school. These possible differences between Girls and Central in the presentation and inculcation of values may be the undefined type of harm ${ }^{63}$ that Vorchheimer feared and which prompted her to attend a coeducational comprehensive school rather than an all-girl academic school. While this difference between Girls and Central may not, by itself, be of constitutional sigmificance, it does make a theory of equal benefit (i.e., separate but equal) less tenable.

In summary, it must be noted that the current uncertainty about the practical application of the intermediate standard of review in the area of sex discrimination makes it mipossible to state with confidence that separate but equal single-sex schools deny equal protection to girls. The problem in Vorchheimer, of course, is that Girls High is separate from, but not equal to, Central. The Philadelphia school district offered meager quasi-scientific data which suggest certain general benefits stemming from segregating children by sex, but presented no evidence that the achievement of Philadelphia's academically gifted students is higher in sex-segregated schools than in coeducational schools. Absent a showing that at least some educational interest of the school system is advanced by sex segregation, the classification should fall under even the most deferential equal protection review. The maintenance of an overwhelmingly coeducational system appears to negate the existence of a substantial city interest in segregating by sex-the discrimination is not backed by an "important" governmental objective. ${ }^{64}$ Since Philadelphia does not offer a coeducational alternative to academically gifted girls, the refusal to admit girls to the city's finest school must be seen as an impermissible denial of equal protection.

62. $400 \mathrm{~F}$. Supp. at 329.

63. Id. at 328 .

64. See text accompanying note 34 supra. 


\section{The EEOA: SeX as A PROHibited Classificatory Basis}

The Equal Educational Opportunities Act ${ }^{65}$ became law in 1974 in essentially the same form as the unsuccessful 1972 bill of the same name ${ }^{66}$ proposed as part of President Nixon's "Busing Moratorium." 67 The unambiguous objective of the legislation was to curtail the use of busing to achieve racial balances in public schools. The significance of the Act to the problem of single-sex public schools lies in the fact that sex is generally included with race, color and national origin as a prohibited basis for the maintenance of dual school systems. If applicable, the EEOA should be dispositive of the Vorchheimer question. ${ }^{68}$

65. 20 U.S.C. $\S \S 1701-1758$ (Supp. IV 1974). The Act provides in part:

Sec. 1701(a). The Congress declares it to be the policy of the United States that(1) all children enrolled in public schools are entitled to equal educational opportunity without regard to . . . sex . . . .

Sec. 1702(a). The Congress finds that-

(1) the maintenance of dual school systems in which students are assigned to schools solely on the basis of .... sex ... denies to those students the equal protection of the laws guaranteed by the fourteenth amendment . . . .

Sec. 1703. No State shall deny equal educational opportunity to an individual on account of his or her ... sex . ... by - (c) the assignment by an educational agency of a student to a school, other than the one closest to his or her place of residence within the school district in which he or she resides, if the assignment results in a greater degree of segregation of students on the basis of . . . sex ... among the schools of such agency than would result if such student were assigned to the school closest to his or her place of residence within the school district of such agency providing the appropriate grade level and type of education for such student ....

Sec. 1705. [T] he assignment by an educational agency of a student to the school nearest his or her place of residence which provides the appropriate grade level and type of education for such student is not a denial of equal educational opportunity or of equal protection of the laws unless such assignment is for the purpose of segregating students on the basis of . . . sex....

66. H.R. 13915, 92d Cong., 2d Sess. (1972). The Ninety-second Congress produced volumes of testimony and debate on this Bill, and the Vorchheimer majority went to great lengths to ascribe to the Ninety-third Congress, which passed the EEOA, what were perceived to be the sentiments of the earlier Congress. In 1972, so-called "Title IX" legislation was enacted which prohibited grants of financial assistance to educational institutions which discriminate on the basis of sex. 20 U.S.C. $\S 1681$ (Supp. III 1973), as amended, Act of Dec. 31, 1974, Pub. L. No. 93-568, \& 3(a), 88 Stat. I862. The coverage of this section included only institutions of vocational, professional and graduate education, and public institutions of undergraduate higher education. 20 U.S.C. $\$ 1681$ (a)(1) (Supp. III 1973). The history of this provision indicates that one House version would have applied the prohibition to all educational institutions, including primary and secondary schools. 118 CONG. REC. 5804 (1972) (remarks of Sen. Bayh). At the urging of Senator Bayh, the Senate excluded primary and secondary schools from the Act's coverage. The Vorchheimer majority cited this exclusion from Title IX as support for the proposition that the absence of references to discrimination by sex in the 1972 version of the EEOA indicated congressional approval of single-sex primary and secondary schools. Even if this inference has any basis in logic, it seems doubtful that such a sentiment can be ascribed to a later Congress which expressly added references to discrimination by sex to the EEOA.

67. See 118 Cong. REC. 8929 (1972).

68. Given that the applicability of the EEOA hinges on whether Congress has declared that segregation of schools by sex denies equal protection, the constitutional and statutory grounds for disposition of the case are interrelated. There is no doubt that Congress is authorized under 
Not surprisingly, the records of the debates over the EEOA reveal a preoccupation with busing to achieve racial balance, and the issue of single-sex public schools was never raised. ${ }^{69}$ The non-obvious applicability of the EEOA is demonstrated by the fact that in the Vorchheimer litigation, this legislation was not even mentioned until it was raised sua sponte by the court of appeals. Unfortunately, the inclusion of sex in the language of the 1974 Act is no more revealing of congressional objectives than was the exclusion of sex from the language of the unsuccessful 1972 bill. $^{70}$ If one is to find support for the proposition that the EEOA forbids single-sex public schools, it must be found in the language of the statute. Even if it is proper to give such effect to statutory language when the actual legislative objectives appear to be wholly unrelated, a difficult question remains whether the language of the EEOA compels the termination of single-sex academic schools like Central and Girls.

Section 1701 of the EEOA states flatly that the policy of the United States is that "all children enrolled in public schools are entitled to equal educational opportunity without regard to race, color, sex, or national origin."71 Of itself, this language does not rule out the segregation of schools by sex, provided that such schools are equal. However, the EEOA

Section 5 of the fourteenth amendment to determine what measures need be taken to enforce the guarantee of equal protection. Katzenbach v. Morgan, 384 U.S. 641, 650-58 (1966). Assuming that Congress intended the EEOA as a means to remedy the social inequalities stemming from disparities in educational opportunity, the flat prohibition of single-sex schools would be appropriate legislation to remove an obstacle to the elimination of state-sponsored discrimination. See Cox, The Supreme Court, 1965 Term-Foreword: Constitutional Adjudicatioh and the Promotion of Human Rights, 80 HARV.L. REv.91, 120 (1966). This is true despite the fact that no court has ruled that single-sex schools are violative of equal protection.

It should be noted that Vorchheimer is not a case in which a legal standard applicable pursuant to a statute would be more stringent than the relevant constitutional standard. $C f$. Washington v. Davis, 426 U.S. 229 (1976) (upholding a police testing program which had a racially discriminatory effect, on the ground that constitutional standard in area of racial discrimination demanded showing of discriminatory intent ; Title VII, if applicable, would have given a different result, since it does not require any showing of intent. Id. at 238-39). In enacting the EEOA, Congress purported merely to remedy what it perceived to be a denial of equal protection; it did not enunciate a new standard for the adjudication of cases arising from discrimination by race, sex or national origin. See notes 71-73 infra and accompanying text.

69. See, e.g., 120 CONG. REC. 8229-85 (1974).

70. In trying to ascribe significance to the inclusion of sex in the language of the 1974 Act, the Vorchheimer dissent stooped to the same level of obfuscation as the majority did in attempting to explain the 1972 bill. Judge Gibbons, noting that the successful Esch amendment used the "race, color, sex, or national origin" formulation, pointed out that the unsuccessful Anderson amendment had not included sex as a prohibited basis for school assignments. The defeat of the Anderson amendment was then used to support the proposition that "Congress expressly added sex to the list of prohibited bases for student assignment and consistently refused to delete it." 532 F.2d at 893 (emphasis added). Judge Gibbons failed to inform the reader that the Anderson amendment was rejected not because it deleted the references to sex, but rather because it tended to emasculate the congressional objective-curtailment of busing.

71. 20 U.S.C. $§ 1701$ (Supp. IV 1974). 
includes an express congressional finding that the "maintenance of dual school systems in which students are assigned to schools solely on the basis of . . . sex . . . denies to those students the equal protection of the laws . . . ${ }^{72}$ This finding provides a basis for Vorchheimer's assertion that she was denied equal protection, since Philadelphia indeed operates a dual "system" of academic schools in which assignments are made exclusively on the basis of sex. ${ }^{73}$

When the congressional finding is read in the context of the neighborhood school concept underlying the entire EEOA, it is arguable that Vorchheimer's voluntary application to a non-neighborhood school removed her from the coverage of the Act's assignment provisions. ${ }^{74}$ This contention, however, is not supported by other language in the Act which sets forth the congressional understanding of "neighborhood school." In delineating guidelines for neighborhood assignment plans, Congress stated that:

[T] he assignment by an educational agency of a student to the school nearest his place of residence which provides the appropriate grade level and type of education for such student is not a denial of equal protection of the laws unless such assignment is for the purpose of segregating students on the basis of ... sex ... ${ }^{75}$

By this language, Philadelphia's academic schools would come under the coverage of the neighborhood school provisions for purposes of prohibiting assignments made on the basis of sex, since only these schools provide the type of education appropriate to the abilities of superior students. The statute's language and the interrelationship of its provisions therefore support Judge Gibbons' dissenting view in Vorchheimer that the EEOA is applicable to the single-sex academic schools.

72. Id. § 1702(a)(1).

73. During the extensive hearings on the 1972 bill, the subject of academic schools did not go unnoticed. In his testimony against the EEOA, Kenneth Young, then Assistant Director of the AFL-CIO Department of Legislation, engaged in the following exchange with one of the bill's sponsors, Representative Albert Quie:

Mr. Young: Sure, we like the idea of neighborhood schools when it can be done. But there are loads of children in this country purposely taken away from neighborhood schools. There are handicapped children and endowed children. People often ask to have their children bused beyond the neighborhood. If it can be done for retarded children and endowed children, then, when you have a denial of the 14th amendment it can be done for those children, too. And, any moratorium deprives those children of their rights.

Mr. Quie: Busing of handicapped children is one-way busing; are you talking of one-way or two-way busing?

Mr. Young: I am saying when you talk of the sanctity of the neighborhood school, somehow that doesn't apply when you are talking of handicapped or endowed children.

Hearings on H.R. 1391S, H.R. 13982, and H.R. 15299 Before the General Subcomm. on Education of the House Comm. on Education and Labor, 92d Cong., 2d Sess. 54 (1972).

74. This observation was critical to the Vorchheimer majority's argument against the applicability of the EEOA. See 532 F.2d at 885 .

75. 20 U.S.C. \& 1705 (Supp. IV 1974) (emphasis added). 
The remaining question is whether the EEOA should be applied at all in a context seemingly far afield of the congressional objectives which produced the Act. The first maxim of statutory construction is, of course, that the process of inquiry into legislative objectives must begin with the language of the statute itself. ${ }^{76}$ On its face, the EEOA presents no problems of unclarity or ambiguity; rather, the problem is the complete silence of the legislative history regarding a situation which appears to be controlled by the statute's language. Under such circumstances, the most prudent course of conduct for a court is to give effect to the plain language of the statute, since to do otherwise would be to substitute a judge's estimation of what Congress meant for the best evidence available, that being the finished product of the legislature. The language and concepts contained in the EEOA are not so esoteric or complex that it would be imprudent to give its words their customary meaning, and the absence of legislative history should not alter that meaning. ${ }^{77}$ If a court is to misconstrue congressional intent, it would seem preferable that it err on the side of literalism rather than on the side of judicial speculation. ${ }^{78}$ Therefore, the action of the Vorchheimer majority in declaring that the EEOA could not mean what it says is both in derogation of congressional power and contrary to principled decision-making.

\section{CONCLUSION}

Despite the current uncertainty about the application of the standard of review in the area of sex discrimination, the maintenance of single-sex public schools arguably constitutes a denial of equal protection. The effects of past and present discrimination make it impossible for all-girl schools to offer the same package of benefits, including prestige, alumnae influence and professional contacts, that all-boy schools can offer, even when the all-girl school possesses the same tangible attributes as the all-boy school. Moreover, there is evidence that segregation by sex has undesirable psychological effects on women, who may reasonably perceive their separation from the socially dominant gender as a badge of inferiority. Finally, the cultivation of certain values and professional objectives has been a primary function of the finer all-boy schools, and it is impossible to insure that superior girls will be exposed to the same values of achievement-orientation traditionally inculcated in boys, unless they have access to the same learning environment. In short, in light of the many vestiges of sexism which remain in American society, it is difficult for a fair-minded observer to conclude

76. Jones v. Alfred H. Mayer Co., 392 U.S. 409, 420 (1968); 2A J. SUTHERLAND, STATUTORY CONSTRUCTION $\$ 46.01$ (4th ed. 1973).

77. United States v. Dickinson, 310 U.S. 554, 562 (1940).

78. See United States v. Oregon, 366 U.S. 643, 648 (1961); Ex parte Collett, 337 U.S. 55,61 (1949). 
that an all-girl school can be separate but equal to an all-boy school. If the schools are not equal, application of the Craig standard should invalidate the discrimination.

Independent of these constitutional considerations, the Equal Educational Opportunities Act provides sufficient grounds for opening the doors of schools like Central to girls. Although the legislative history of the EEOA offers no guidance as to congressional objectives, the plain language of the statute evinces an intent to proscribe the kind of discriminatory assignment plan employed by Philadelphia in assigning its intellectually superior students to one of the city's two academic schools. Any attempt by a court to divine a contrary neeaning in the EEOA would be no more than an act of "judicial legislation" deserving quick condemnation. The language of the EEOA should be given effect by the courts; if Congress disagrees with the judiciary's construction of the statute, it has ample opportunity to correct the courts' error. 
. 